\title{
Joy and Autism: Biblical, Theological and Practical Perspectives
}

\author{
Autism is frequently approached as a condition of functional deficit, where the \\ perceived deficit is defined in terms of the individual's measurement against a \\ standard labelled as "normal." The capacity to experience fulfilment is often \\ considered to be compromised by such deficit. As part of a theological evaluation \\ of autism, the concept of joy is seen to function in ways that resist such \\ approaches, for the capacity for joy is not linked to any individual's intrinsic \\ capacity, but rather to the presence and purpose of God, which must take \\ precedence over all other elements in the evaluation of the condition.
}

Keywords: autism; joy; functional deficit; theology.

\section{Introduction}

In this essay, I will explore some of the ways in which joy is represented in the biblical material as a deliberative assertion of, and response to, God's goodness, in the face of the world's values. Joy has implications for how those shaped by the values woven through biblical texts inhabit that world and its experiences, including the particular experience of autism. The one who rejoices properly or faithfully inhabits God's goodness, often in the presence of evil, and refuses the temptation to be defined by anything other than that goodness. As such, joy is interwoven with the moral life of persons and communities: it is responsive, but also deliberative, and shapes the practices of evaluation that each community and its members bring to bear upon their experiences and constitution. As these communities consider the reality of autism, something often represented in the negative terms of deficit or demand, a properly informed practice of joy has the capacity to be radically transformative. While the essay will involve reflection on some key texts in the New Testament, particularly the famous 
commandment to rejoice in Philippians 4:7, the concept of joy will also be informed by reflection upon the Book of Psalms, which has served as the principal resource for praise and prayer for believers through the centuries before and after the earthly ministry of Jesus.

\section{On Autism and its Definitions}

We do not here have space to give a full account of how "autism" has been understood through the decades in which it has been a named thing, and there would probably be limited value in attempting such an account. What we can more helpfully note is that an increasing number of voices from within the autism community have expressed concern at the generally negative representation or even definition of the condition. Autism has typically been defined in terms of functional deficit: it is described as involving a deficient "theory of mind" or a condition of "low empathy," with both of these categories claimed to be "measured" against the "normal" population. The density of quotation marks in that last sentence reflects the fact that this has been accepted technical terminology within the literature of research on autism - which has largely been developed in scientific, social scientific, and clinical journals — and that many who are themselves autistic consider it this language to be inappropriate or incorrect.

One of the critical features of the "functional deficit" approach is easily overlooked, because it is basically assumed within modern value systems: the concept of functional normality or deficit is considered in terms of the capacity of the individual. That is, the function of the individual is measured against an external standard 
considered to be "normal" and the potential of that individual to enjoy happiness or fulfilment is evaluated accordingly. Often the concept of fulfillment is associated with the possibility of "productivity," which introduces a social element to the definitions and discussion. But this social element is of limited significance and, importantly, remains entirely external to the individual in question. This is important, because while the individual may be referred to as a "person," the concept of personhood is conceived entirely in individualist terms. This opens the possibility that if the individual in question is considered abnormal or subnormal to a sufficient extent, when judged against the functional standard assumed, their very status as a person can be called into question, examples of which will be noted below. Often, the functional standard is that of "autonomy," the capacity of the individual to live without care and oversight provided by another individual or institution.

A wide range of philosophical and theological discussion-often subsumed under the broad term "personalism" (Smith, 2010)— -has critiqued the tendency to identify personhood in individual terms. Charles Taylor, famously, has noted that the modern conception of the "self" or "person" sees the individual in self-subsistent or self-contained terms, as if what that individual is can be considered in isolation from the matrix of relationships within which that individual exists (Taylor, 2007). This is Taylor's often-cited concept of the "buffered self," which he contrasts with pre-modern (and non-Western) notions of the "saturated self": the person whose being is constituted by a world of relationships with other persons and realities, both natural and otherwise. Phenomenology, as a philosophical discipline, has been particularly sensitive to this, developing the language of "relational ontology" to articulate the recognition that what a person "is" - their ontology — is inseparable from their relational matrix. The confusion of the lower concept of the individual with the emergent reality of the person 
(see Smith, 2010) is one that leads to distorted and distortive evaluative accounts. In moral philosophy, this is a key element in Alasdair MacIntyre's analysis of the failings that doom contemporary ethics (MacIntyre, 1981): modern ethics have largely reified the individual into the entity to which rights and value are attached, but often assuming a functional standard against which the "personhood" of that individual can be measured. If they are considered to fall short of that standard, their status as persons is jeopardized, and with it their claim to value and rights. In medical and clinical research, this is reflected in the language of "normality" and "abnormality," which is often deployed in its statistical sense (to indicate ranges of data), but which eventually comes to label the individual according to their perceived approximation of humanity. In autism discussions and research, this can be reflected in a use of language that attaches a certain sense of exceptionality to those autistic individuals who can enjoy genuine and productive relationships, as if they are the exceptions that prove the rule (and who are so only because of interventions by "normal" people).

Philosophy and theology have long recognized the inherent dangers in the language of "normalcy" or "normality": such language is often used in the service of power, supporting the agendas of those in power to marginalize those with whom they disagree, or subconsciously expressing our preference for those who are like ourselves (so, famously, Foucault 1961 and 1975). Crucially, such approaches are targeted to the individual and their perceived intrinsic qualities. Sometimes, such definitions of normality serve as the basis for decisions concerning the status and associated rights of the individual who is deemed "abnormal" or "deficient," even to the extent of questioning their status as "persons." Medical models that approach or define autism principally or largely in terms of deficit have underpinned explicit categorizations of autistic people as sub-personal, notably in the work of Peter Hobson (see the discussion 
in Barnbaum, 2008, and the recent online article by Loughran, 2019). Such approaches lead to distortive representations of the autistic person's capacity for relationship, which has in turn underpinned some theological approaches that use autism as an image of sub-relational existence (Stump, 2010).

Challenging such use of "deficit" language, and its often-unintended implications, a movement has grown within the autism community that prefers to use the language of difference or diversity, with the specific term "neurodiversity" serving as something of a catchword for this. This neutralizes the moral assumptions within the concepts of normality, while still leaving space to recognize that the differences may be disabling for individuals, sometimes because the world's processes are built around those regarded as "normal." This diversity-based approach seeks constructively to highlight and disrupt the assumption of normality and, for obvious reasons, has often aligned with similar movements related to other experiences of diversity (ethnicity and sexuality).

This intersects in interesting ways with the use of the concept of joy in the biblical material, which often has a somewhat disruptive or surprising quality: we would normally expect a certain set of circumstances or experiences to elicit joy in those able to enjoy them, but the concept often runs counter to such expectations, dissociating joy from them and reattaching it to circumstances that we might expect to bring only misery. In doing so, it slices across the values of normalcy themselves and this has to be allowed to inform a theological evaluation of the autistic experience, as well as speaking into that experience.

But the concept of joy, approached in biblical and theological terms, moves beyond this disruption of expectations to a more thoroughgoing reorientation of the 
perceived basis for happiness and fulfillment. Where, as we have seen, "fulfillment" is typically approached as something made possible by the functional capacity of the individual, defined according to a presumed standard of normality, the biblical concept of joy attaches the possibility of fulfillment to the presence of God and his involvement in the economy of his dealings with all that is outside of Godself. This is true for all creatures, not just those who might be seen to lack something that others have. The deliberative or intentional quality of joy, as it is represented in the Bible, begins to highlight this essential difference from modern notions of fulfillment.

\section{Joy as a Deliberative State: The Commandment to Rejoice}

In Philippians 4:4, Paul famously instructs the church in Philippi:

Rejoice in the Lord always. I will say it again: Rejoice! ${ }^{1}$

Chairete en kyriō pantote; palin erō, chairete

This is not the first time he has issued this instruction to his readers in this letter; he does so also in Phil 3:1. Interestingly, in both cases, the instruction to rejoice is closely_even causally_linked to a protection of some sort from moral evil. In 3:1, Paul follows his exhortation to rejoice with these words:

Finally, my brothers, rejoice in the Lord! It is no trouble for me to write the same things to you again, and it is a safeguard for you (hymin de asphales).

\footnotetext{
${ }^{1}$ Unless otherwise indicated, all quotations from the Bible are taken from the 1984 version of The Holy Bible, New International Version® NIV®. Copyright @ 1973197819842011 by Biblica, Inc. TM. Used by permission. All rights reserved worldwide.
} 
Even if these words anticipate the guidelines that follow, which contain specific pieces of moral advice, their close apposition to the joy-imperative seems to associate it with the function of a "safeguard." When Paul reiterates and repeats the commandment in Phil 4:4, he expands the positive exhortation with a further directive to engage in petitionary prayer about the causes of worry, a directive that is paired with its negative corollary, that anxiety cannot be allowed to remain unchecked:

Do not be anxious about anything, but in everything, by prayer and petition, with thanksgiving, present your requests to God. (Phil 4:6)

Given that anxiety commonly co-occurs with autism, it may be important to note an important point of grammar that is somewhat obscured in English translation. The form used here (a negated present imperative) is often associated with commandments or prohibitions that disallow the continuation of a particular activity, rather than its initiation (which would normally be prohibited using an aorist subjunctive). While this point of grammar cannot be taken as a strict rule, it is probably relevant to the interpretation of this verse, which is really concerned with whether anxiety is allowed to continue unaddressed, or is challenged by the intentional practice of joy. In other words, we do not break the injunction simply because we have begun to feel anxious, but only when we allow anxiety to remain and to escalate, with all its destructive effects.

The prohibition of anxiety and exhortation to prayer leads directly to another statement concerning the protective quality of peace:

And the peace of God, which transcends all understanding, will guard your hearts and your minds in Christ Jesus. (Phil 4:7)

That the act of rejoicing appears so closely linked to the protection of hearts and minds 
is more significant than we might initially appreciate. While today the heart is often popularly seen as the seat of emotion, and the mind as the seat of the intellect or rationality, both body parts were, in classical terms, associated with processes of cognition and volition. To protect the heart and mind is not simply to have emotions and beliefs protected, as moderns might assume, but to have volitional decisions and perceptions guarded from the values that would distort them. This association of rejoicing with perceptive and volitional cognition is reflected in the following verse, where Paul continues by asking his addressees to think about whatever is good, lovely and praiseworthy (Phil 4:8) and then to implement what Paul has taught (Phil 4:9), in order to enjoy the presence of "the God of peace," a title that links back to Phil 4:7, with its reference to the peace that "transcends all understanding (nous)."

On one level, to describe God's peace as something that "transcends all understanding" is to acknowledge that it is not subject to the kinds of logic by which we would normally consider a situation conducive to peace. As such, it challenges the validity of those logics themselves. It also, however, represents the peace in question as something that is not contingent upon a particular kind of cognition: the capacity to enjoy this peace does not rest upon a particular cognitive or noetic state-we do not need to be cognitively able in order to enjoy it. In fact, by linking this peace to the active presence of the God of peace, in Phil 4:9, the text depicts peace as something that originates outside of the individual self or mind state; specifically, peace emerges from the presence of the God of peace.

I begin with these observations about the biblical commandment to rejoice because they jar somewhat with contemporary discourse, where joy is typically seen as entirely and spontaneously responsive to conducive circumstances, as these are experienced by one who conforms to a particular pattern of ability. This is often 
associated with a particular set of assumptions about what it means to be "fulfilled." As we shall see below, joy is indeed properly understood as a response to God, but it is not necessarily a spontaneous one. Rather, it is a deliberative one: it is something that can be the content of a commandment, as here, because the person or community can commit themselves intentionally and consciously to the act of rejoicing. This deliberative act, moreover, is represented as a nodal act, one that redirects other cognitive events, whether epistemic or volitional. Those who rejoice thereby evaluate and decide more "safely": their perceptions and choices are altered for the better by their commitment to joy. Without pressing this observation too far, we might also notice that Paul's commandments are plural in form: he writes to a community or group and expects this too affect the way that the group thinks.

\section{Rejoice in the Lord: The Object, Context and Source of Response}

Joy is not an abstracted concept of happiness in the biblical material. The commandment in Philippians 4:4 is not nakedly an exhortation to be happy, but rather to rejoice "in the Lord." When considered in relation to Paul's broader theology, and in relation to the wider biblical material, this act of defining joy as "in the Lord" can be seen to have three linked elements.

First, "the Lord" is the object of joy, the thing to which attention is directed that elicits such a response. Contextually, in Paul's letter to the Philippians, the command is an acknowledgement of the temptation to look to other objects of attention or performance as sources of joy or fulfillment in their own right, taken apart from their value as gifts from God. Following the first occurrence of the exhortation, in Philippians 3:1, Paul warns against "the mutilators"- those who put their confidence "in the flesh" (3:2-3) - before continuing to narrate his own participation in such a value system. The 
reference to "mutilators" probably indicates the groups pressing for the observance of traditional Jewish practices such as circumcision, but Paul's list of his own reasons for boasting moves beyond this and points to various claims to status that he previously considered to be "gain." These constitute what we might today think of as social or symbolic capital: the things true of Paul (or how he is perceived) that caused people to think of him as more significant or valuable than others. Contextually, the proximity of this account to the command "rejoice in the Lord" suggests a deliberate focus of attention upon the Lord as source of joy, rather than upon such social capital.

This theme is widely found in the Psalms, often linked to the theme not just of divine provision or providence, but of divine presence:

But let all who take refuge in you be glad;

let them ever sing for joy.

Spread your protection over them.

that those who love your name may rejoice in you. Psa. 5:11

You have made known to me the path of life;

you will fill me with joy in your presence, with eternal pleasures at your right hand. Psa. 16:11

Surely you have granted him eternal blessings and made him glad with the joy of your presence. Psa. 21:6 Joy, here, is a corollary of God's acknowledged presence. 
Second, the qualifier "in the Lord" points to the Lord as the context in which the act of rejoicing takes place. This reflects a theme that can be traced across the New Testament writings, that the union established between Jesus and his people (by which they are in turn united to God) is properly described in terms of inclusion or belonging: we are not simply followers of Christ, but are represented as his "members" (cf. 1 Cor 12). Our joy is precisely his joy, because is it the joy experienced within his body. Paul, in particular, develops a rich account of the Christian community in such terms, using prepositions that reflect this emphasis on belonging (particularly his favoured term, "in Christ”, see Campbell, 2012), which is what we see here. Across the New Testament, however, we can trace a similar emphasis, often developed through distinctive metaphors, such as John's image of the vine and its branches, and the image of the community as temple, found explicitly in Acts 15 and in 1 Peter 2. For the present essay, this is relevant because it highlights the intersection of the theme of joy with that of belonging. We will unpack the significance of this below.

As a corollary of this, we can note a third implication of the construction "Rejoice in the Lord," which is that the Lord-as the Head and Source of the community's life and identity—is the source of the joy itself. Joy does not spontaneously spring up from our own resources, but is itself a gift shared with us by God. This again reflects some of the themes that we see elsewhere in Scripture, notably in the Psalms, where joy is seen as something given by God:

You have filled my heart with greater joy than when their grain and new wine abound. (Psa. 4:7)

You turned my wailing into dancing; you removed my sackcloth and clothed me with joy. Psa. 30:11

While these observations are essentially framing considerations for a proper theology of 
joy, they are immediately relevant to how we approach or experience autism joyfully. First, the proper theological starting point for thinking about autism is thinking about a God who is the cause and source of joy, a good God. In the terms of Christian theology, we must consider autism in terms of divine economy (God's dealings in creation, providence and redemption with all that is outside of Godself), as something graced by God's care and presence, before we consider it in relation to earthly economies and human experiences that are commonly labelled as "normal." This is particularly important, because human "normality" will always become an alienating, excluding and diminishing concept — a form of ableism that sees "abnormality" always in terms of deficit or deviation - if it is not carefully framed by theology proper, that is, by the assertion of God's goodness as a prolegomenon to all attempts to ascribe value.

Furthermore, theological challenges to ableism need to be rightly grounded. If we are attentive to the biblical treatment of joy, we will not seek to begin with a reconceiving of God as disabled, a God with whom we can identify our frailties (contra the approach of Eiesland, 1994); rather, we will begin with reflection upon a Holy God who can resource creatures (all creatures, not just those who are disabled) in their frailties. The key to this is a proper affirmation of the humility of God-his powerful willingness to make himself present with those of all status (cf Pardue, 2013; Macaskill, 2018) - and not a confusion of the categories of creature and creator intended to make God seem more relatable. The problems with such as approach are effectively probed by Kathryn Tanner, who notes the modern tendency to extinguish transcendence in accounts of how God relates to the creation and its history (Tanner, 2001). Paul's commandment to rejoice, and his description of the peace that is associated with this joy, seems to make no concessions to such an approach; rather, it is in line with the biblical tendency to affirm divine transcendence and plenitude as the grounds for hope. 


\section{Joy as Economically Subversive: Rejoice Always and Give Thanks for All Things}

The command to "rejoice in the Lord always" has a somewhat subversive function that we must not pass over too quickly. We might consider "hope" to be an appropriate condition to occupy when we are in a difficult economic situation, because this involves a conviction that a period of present distress will not last. Indeed, there are some points in the Psalms where a future joy is anticipated with hope:

Weeping may remain for a night, but rejoicing comes in the morning. (Psalm $30: 15)$

At multiple points in Scripture, notably in the prophetic writings, an eschatological future is represented as a time characterized by joy, as in Isaiah:

You will go out in joy and be led forth in peace; the mountains and hills will burst into song before you, and all the trees of the field will clap their hands. (Is. 55:12)

Then you will look and be radiant, your heart will throb and swell with joy; the wealth on the seas will be brought to you, to you the riches of the nations will come. (Is. 60:5)

As the second of these quotations, written from the standpoint of national ruin, indicates, such expectations of future joy often involve a hope that current economic conditions will be reversed: the powerful will be brought down and the poor will be raised up, enjoying the wealth of those who once oppressed them. Joy and hope are thereby coordinated.

But Paul's command to rejoice always is patently directed towards the reframing 
and revaluing of present circumstances, and this demands of the one who rejoices a commitment to seeing those circumstances in different terms. This becomes clear in the following verses. Paul first articulates his grateful joy at the renewal of concern that the Philippians have expressed for him, presumably in relation to the possibility of a gift or of support (4:10). He disclaims any need,

for I have learned to be content whatever the circumstances. I know what it is to be in need, and I know what it is to have plenty. I have learned the secret of being content in any and every situation, whether well fed or hungry, whether living in plenty or in want. I can do everything through him who gives me strength. (Phil 4:11-13).

Again, the premise of contentment — apparently in parallel with rejoicing — lies neither in Paul's own state of being, or in his circumstances, but in the presence of the God who gives strength. This is not to say that there is not an orientation towards a transformed future for Paul, but what he points to here as the grounds for his contentment and joy is something already present.

A similar sentiment is expressed in 1 Thessalonians 5:16-18. There, Paul writes: Be joyful always; pray continually; give thanks in all circumstances, for this is God's will for you in Christ Jesus.

The parallelism of thought with Philippians 4 is quite striking, which is all the more striking because the earlier part of the chapter has been concerned with the expectation of Christ's return, and of the eschatological upheaval that will accompany it. 
When brought to bear on the systems by which we ascribe economic value to people or to circumstances, this is fundamentally subversive. Often, our language of "normality" decides on a particular embodiment of functionality or on a particular notion of fulfillment that becomes the measure of the person's perceived worth or potential. If one deviates from this measure, one is considered less valuable or important. If one can never attain to certain possible outcomes, one is considered doomed. The approximation of these measures by the disabled may be celebrated as a kind of "overcoming" or as a sort of near-normality, but it is always labelled as lesser to the experience of those who see themselves as normal. In some cases, such evaluations lead to the conclusion that the person's life is simply not worth having. But Paul's representation of joy, drawing as it does upon the biblical traditions, refuses to allow such economical decisions to be made on the basis of the individual's approximation of "normality" or the circumstances they will experience. Joy is premised on participation in the divine economy. We might suggest that this has some implications for concepts such as "quality of life" or "family quality of life," which are often deployed in the statistical analysis of circumstances. At least in theological discourse, the extent to which these measures are wrapped up in modern economical ways of ascribing value needs to be recognized.

\section{Joy and Autism: A Concluding Synthesis.}

While we have offered some comments along the way in this essay, to consider how our findings might relate to autism, we are now in a position to draw some threads together by way of concluding synthesis.

First, the concept of joy - understood in terms informed by biblical and theological material—demands that a theological evaluation of autism refuses to 
measure value according to a standard of individual function or fulfillment. As we have seen, autism is commonly conceived as a condition of functional deficit, where the individual and their capacities are measured against an external standard of function and fulfilment. While there is a "social" aspect to such approaches, this is still understood in terms of the capacity of the individual to participate in social interactions, or to contribute to a social good through their productivity. The concept of joy that we have studied above, however, does not begin with any model of value that is reducible to individuals and the capacities that they are judged to have. Importantly, this is equally true of the "able" person and the "disabled" person: the capacity for joy is not determined by the condition of the individual, but by the locatedness of that individual within a world saturated by God's presence and goodness. This cuts equally across our association of fulfillment with productivity. When a thing — any thing —is located within an economy of gift and grace, its state of fulfillment or the attainment of its telos - can no longer be evaluated in terms of its capacity to generate other things for the consumption of the group (productivity), but in terms of its participation in God's sharing of life with the creation. There is no space in such discourse for labels such as "high functioning" and "low functioning," for they are defined in relation to some notion of social productivity. It is simply meaningless to speak of a "high-" or "low functioning" participant in grace, or to speak of "high-" or "low functioning creatures." This would seem to have significant implications for those theological approaches to autism that have bought into and built upon the functional deficit model, such as that of Stump (Stump, 2010) and McFall (McFall, 2016).

Second, groups that take seriously the commandment to "rejoice in the Lord always," with its subversive economic overtones, should be shaped by the deliberative processes involved in the commandment, so that their valuing of autistic persons in their 
midst is based on the principle of gift, rather than those principles of function and productivity that mark clinical approaches to autism. Yet, and this is vital to note, the very fact that the exhortation to rejoice is a commandment, that it involves deliberation and does not happen spontaneously, highlights that our natural or instinctive values need to be volitionally addressed. It is both naïve and misleading to expect that churches will automatically be safe places for autistic people and their families, wherein those with autism will be properly valued and treated accordingly. Rather, they will be places where typical value systems continue to be operate, but are continually exposed by the values of faith, provided the commandment to rejoice in the Lord always is taken seriously.

Third, while there is indeed an eschatological dimension to joy, which points forward to a time of reversal and transformation, this cannot be allowed to define our notions of joy in ways that displace or efface its radically re-evaluative implications for our present condition. For autism, in particular, this is important. It is common in Christian circles for autism (like disability, in general) to be seen as something presently debilitating, which will be transformed in an eschatological future. The relevance of joy, in this case, would be that of the one who rejoices in the knowledge that the present time, and all of its frailties, is not the final or permanent condition in which we will remain. But while there is clearly an anticipation of future transformation in the New Testament (as in, for example, 1 Cor 15), and a proper emphasis on hope, it is only by extrapolation and by assumption that we can see this as a time when all disability will cease to be: the Scriptural texts do not clearly indicate this to be the case. For many within the autistic community, just as for many with disabilities, the prospect of the condition being eradicated in the eschaton is actually a troubling one, since it is so foundational to their identity. This is not to say that every disability will continue into 
the eschaton, but rather to acknowledge two things. First, the disabling that is part of the autistic experience often has its origins in the way the world is constructed to suit nonautistic identity, rather than in autism itself. What may change in the eschaton is the world, and its value system, so that the "autistic gain" is rightly appreciated. In a real sense, conditions may cease to be disabilities, for the values and priorities in the external world that result in persons being functionally disabled by their conditions may be transformed; but the conditions themselves may remain. Second, our notions of healing and wholeness are often subverted by the modern preoccupation with autonomy and self-subsistence, and not simply shaped by the appropriate hope for a life without pain. If we allow that this preoccupation may cause us to dismiss the proper experiences of creaturehood as sub-optimal, or even as sub-human, then we can begin to see how our hope itself is distorted by a particularly modern lens. If the concept of joy is properly understood as something that re-values present circumstances by relating them to the economy and presence of God, the possibility that these circumstances and conditions will extend into the eschaton actually ceases to be unthinkable, even as our hope for a world in which the healing and the justice of God are manifest grows. 


\section{Bibliography}

Barnbaum, Deborah. 2008. The Ethics of Autism: Among Them But Not of Them.

Bloomington and Indianapolis: University of Indiana Press.

Campbell, Constantine. 2012. Paul and Union with Christ: An Exegetical and Theological Study. Grand Rapids: Zondervan Academic.

Eieseland, Nancy. 1994. The Disabled God: Towards a Liberatory Theology of Disability. Nashville: Abingdon Press.

Foucault, Michel. 1975. Discipline and Punish: The Birth of the Prison. Translated by Alan Sheridan (1977). London: The Penguin Group.

1961. Madness and Civilization - A History of Insanity in the Age of Reason.

Translated from the French by Richard Howard (2001). New York: Routledge.

Loughran, Elle. 2020. “The Rampant Dehumanization of Autistic People,” The Aspergian. Published online: https://theaspergian.com/2020/01/06/the-rampantdehumanization-of-autistic-people/

Macaskill, Grant. 2018. The New Testament and Intellectual Humility. Oxford: Oxford University Press

Macaskill, Grant. 2019. Autism and the Church: Bible, Theology, Community. Waco: Baylor University Press.

MacIntyre, Alasdair. 1981. After Virtue. Notre Dame: University of Notre Dame Press. 
McFall, Michael T. 2016. "Divine Hiddenness and Spiritual Autism.” Heythrop Journal 57 (6). Published online.

Pardue, Stephen. 2013. The Mind of Christ: Humility and the Intellect in Early

Christian Theology. London: Bloomsbury T\&T Clark.

Smith, Christian. 2010. What is a Person? Rethinking Humanity, Social Life and the Moral Good from the Person Up. Chicago: University of Chicago Press.

Stump, Eleonore. 2010. Wandering in Darkness: Narrative and the Problem of Suffering. Oxford: Oxford University Press

Tanner, Kathryn. Jesus, Humanity and the Trinity: A Brief Systematic Theology. Minneapolis: Fortress Press, 2001.

Taylor, Charles. 2007. A Secular Age. Cambridge, MA: Harvard University Press. 